\title{
Processo de produção e transformação da forma urbana em cidades costeiras brasileiras
}

\author{
Denio Benfatti \\ Pontifícia Universidade Católica de Campinas, Pq. das Universidades Campinas, \\ 13086-900 Curitiba SP. E-mail: deniobenfatti@puc-campinas.edu.br \\ Vera Tângari \\ Universidade Federal do Rio de Janeiro, Av. Pedro Calmon $5504^{\circ}$ andar, Cidade \\ Universitária, 21941-901 Rio de Janeiro RJ. E-mail: vtangari@uol.com.br
}

Artigo revisto recebido a 7 de Novembro de 2017

\begin{abstract}
Resumo. $O$ universo da pesquisa nacional, objeto do Projeto Temático FAPESP 'Espaços livres e forma urbana', coordenada pelo laboratório QUAPÁ-SEL da FAUUSP, engloba 35 cidades, dentre capitais e cidades de porte médio no Brasil, e se pauta em procedimentos que incluem: pesquisas em rede, individuais e em grupo; oficinas de trabalho nas cidades estudadas; colóquios de pesquisa anuais; divulgação em eventos científicos nacionais e internacionais. Neste artigo são enfocadas cidades localizadas na costa litorânea brasileira onde já ocorreram oficinas e que possibilitaram a sistematização de alguns resultados e uma aproximação de cunho comparativo: Vitória, Salvador, Maceió, Santos e Recife. O texto inclui reflexões sobre o objeto pesquisado e comparações entre as cidades e conclui por indicar para debate possíveis critérios de intervenção para as cidades estudadas que gerem qualidade urbana, resguardadas as situações socioambientais particulares a cada uma. Nesta reflexão, ao invés de discorrer sobre todas as linhas de investigação propostas para as oficinas realizadas pela rede QUAPÁ-SEL, resolvemos traçar um recorte parcial sobre uma pesquisa em andamento, e esta reflexão selecionou apenas parte delas que tem em comum o fato de se situarem na costa brasileira. A reflexão se ateve basicamente aos resultados das oficinas, o que traz para esta análise uma simplificação e ao mesmo tempo uma dificuldade. As oficinas e os respectivos relatos apresentam-se de forma bastante heterogênea e desigual. Entretanto, as discussões foram sempre pautadas em função das mesmas linhas de investigação, assegurando, por outro lado, uma homogeneidade na abordagem.
\end{abstract}

Palavras-chave: forma urbana, espaços livres, litoral, QUAPÁ-SEL, Brasil

\section{Introdução}

Passados alguns anos de desenvolvimento de pesquisa sobre 'espaços livres e forma urbana nas cidades brasileiras', consideramos sobremaneira importante trazer ao debate alguns casos específicos, como forma de aprofundar a análise. As cidades costeiras de Santos, Vitória, Salvador, Recife e Maceió são os objetos específicos deste aprofundamento.

A análise proposta permitirá revisitar e comparar situações e etapas distintas que cada uma destas cidades apresenta atualmente com relação ao tema tratado. Estas cidades, apesar de algumas 
semelhanças, apresentam um desenvolvimento desigual umas em relação às outras. Tanto os tempos, como as intensidades, os efeitos e as respostas das administrações públicas têm sido muito distintas. Portanto as comparações aqui realizadas devem ser consideradas como segmentos de realidades complexas e que se aplicam apenas parcialmente.

Procuramos combinar uma abordagem mais ampla e ao mesmo tempo restrita dos resultados das oficinas realizadas nestas cidades e das linhas de investigação propostas pelo coletivo de pesquisadores do QUAPÁ-SEL. A pesquisa propõe quatro linhas de investigação, observadas pelos pesquisadores e pelos demais participantes das oficinas realizadas nas cidades analisadas: i) sistemas de espaços livres e sua relação com a forma urbana e elementos estruturais (praças, parques, espaços de convívio, lazer e conservação ambiental); ii) padrões morfológicos (fisiografia de quadras, lotes, edificações); iii) processo de produção das formas urbanas (principais agentes e produtos); e iv) legislação urbanística, parcelamento e uso e ocupação do solo (modelagem de situações típicas).

A nossa reflexão enfocou os resultados das oficinas, o que traz uma simplificação e ao mesmo tempo uma dificuldade. As oficinas e os respectivos relatos sobrepuseram várias camadas de heterogeneidade: tiveram dinâmicas e resultados desiguais; e os relatos dessas experiências foram realizados por pesquisadores diversos, apresentando relativa heterogeneidade. $O$ que assegura alguma homogeneidade, e nos permite estabelecer uma análise comparativa, é o fato das oficinas terem sido realizadas e relatadas a partir das quatro linhas de investigação descritas.

Apesar desta aparente e óbvia dificuldade, parece-nos que a tentativa de comparar e refletir sobre situações urbanas distintas, com processos históricos e dimensões distintas e submetidas a processos igualmente distintos de expansão nestas ultimas décadas, poderá nos permitir vislumbrar indícios novos de adequação metodológica e de critérios tanto para a leitura quanto para possíveis ações sobre o território.

Para o esforço de comparar as situações urbanas analisadas, iniciamos por montar um quadro analítico com dados objetivos.

\section{A montagem de um quadro analítico homogêneo}

A partir dos resultados das oficinas procuramos complementar algumas informações para obter uma base de dados comum. A primeira informação, de caráter geral, diz respeito à localização das cidades nos biomas brasileiros. Para esta caracterização utilizamos como fonte o mapa de biomas construído por Aziz Ab'Saber (2003). As cinco cidades litorâneas - Recife, Maceió, Salvador, Vitoria e Santos encontram-se no bioma Mata Atlântica (Figura 1).

A complementação da análise a partir da consideração da inserção no bioma mostrouse de extrema importância em função das características de processo de urbanização, principalmente o que passou a ocorrer a partir dos anos 1970, cujas características predominam atualmente em termos de área urbanizada. Grande parte desta expansão urbana, de baixa densidade e consumidora de solo, tornou mais aguda a tensão entre os processos de urbanização e o ambiente natural, ou, de modo mais preciso, os espaços urbanos não construídos (espaços dedicados à agricultura, reminiscências florestais, áreas de mangue, etc.).

Nas cidades de Santos e Vitória o bioma é mais amplo, adentrando o interior com incidência de morros mais altos. Já nas demais cidades o bioma Mata Atlântica ocupa apenas uma estreita faixa litorânea, na transição para a caatinga. Nestas cidades a topografia dos morros é mais arredondada, com a presença de tabuleiros, grotas e dunas.

Nas cinco cidades, verifica-se a presença de mangues e áreas alagadas. Apesar de diversos, estes elementos são fortes condicionadores da urbanização, da existência de espaços livres de ocupação e da ocorrência de ocupação em áreas impróprias (mangues e alto dos morros). Outros itens acrescentados a essa análise incluíram: localização, população, dimensão e suporte 


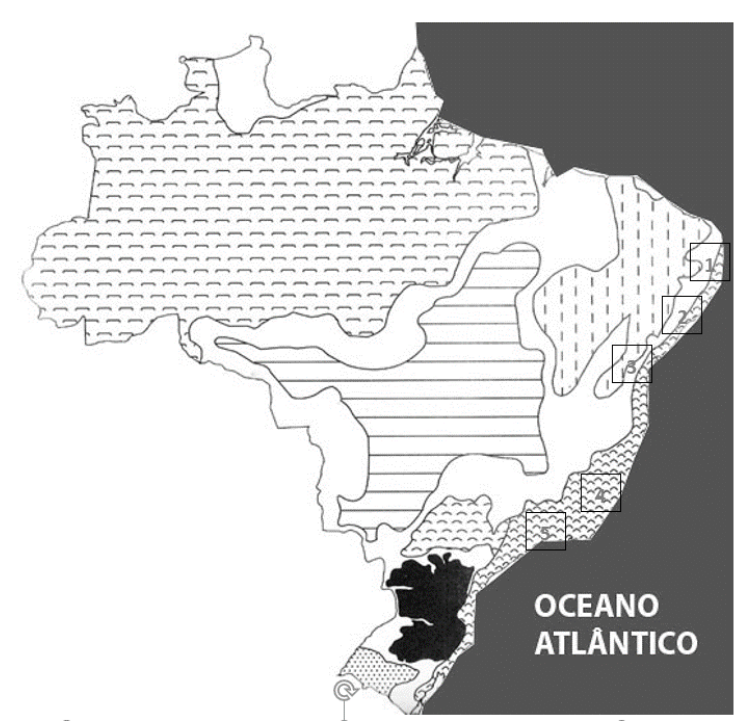

I - Amazônia: Terras baixas cobertas por floresta equatorial

II - Cerrado: Extensas planícies cobertas por cerrados e florestas de galeria

III - Mata Atlântica: Concentração expressiva de morros cobertos por mata atlântica

IV - Caatinga: Terras baixas rodeadas por colinas e terras altas cobertas por caatingas

V - Araucárias: Planícies altas subtropicais cobertas por florestas de araucárias

VI - Pradarias: Campos baixos subtropicais com prados mistos

Figura 1. Biomas brasileiros - localização das cidades estudadas - 1. Recife, 2. Maceió, 3. Salvador, 4. Vitória, 5. Santos (fonte: Jonathas Magalhães Pereira da Silva a partir de Ab'Saber, 2003).

físico. Quanto aos demais, usamos dados e informações presentes nas oficinas: Sistema de espaços livres / Padrões morfológicos / Processos de produção / Legislação urbanística.

\section{As cidades analisadas}

Nesse item sistematizamos dados gerais sobre cada cidade, para termos um panorama das informações demográficas, econômicas, político-administrativas e dos aspectos do suporte geo-biofísico. As cidades apresentam relevo distinto entre a localização na região sudeste (Santos e Vitória), relevos mais acidentados, e na região nordeste (Salvador, Recife e Maceió), relevos mais suaves e com a formação de tabuleiros e escarpas. A vegetação original se compunha de espécies de Mata Atlântica com incidência de ecossistemas de restingas, no sudeste, e grotas, lagoas, dunas e praias, alagadiços e restingas, no nordeste. Todas são sede de regiões metropolitanas. A seguir são apresentadas as informações coletadas durante as oficinas e complementadas pelos autores.

\section{Recife}

Recife é capital do Estado de Pernambuco e se localiza na Região Nordeste. Apresentava em 2014: população de 1.608.488 habitantes; área de 218. $435 \mathrm{~km}^{2}$; densidade: 7.363,69 Hab. / km²; IDH: 0,772. O PIB / per capita em 2012 era de R\$23.679,08 / US\$ 11.587,51 / € 8.785,00. Em relação ao suporte físico, apresenta altitude de $4 \mathrm{~m}$. O seu território, de uma forma geral, compreende $67 \%$ de morros, $23 \%$ de planícies, $9 \%$ de áreas aquáticas, $6 \%$ Zonas Especiais de Preservação Ambiental, com incidências de grotas, lagoas, praias e alagados. O município é cortado pelos rios Beberibe e Capibaribe, articulado por pontes, formando ilhas - Santo Antônio, São José e Bairro do Recife. A vegetação apresenta cobertura original em Mata Atlântica (Figura 2). 

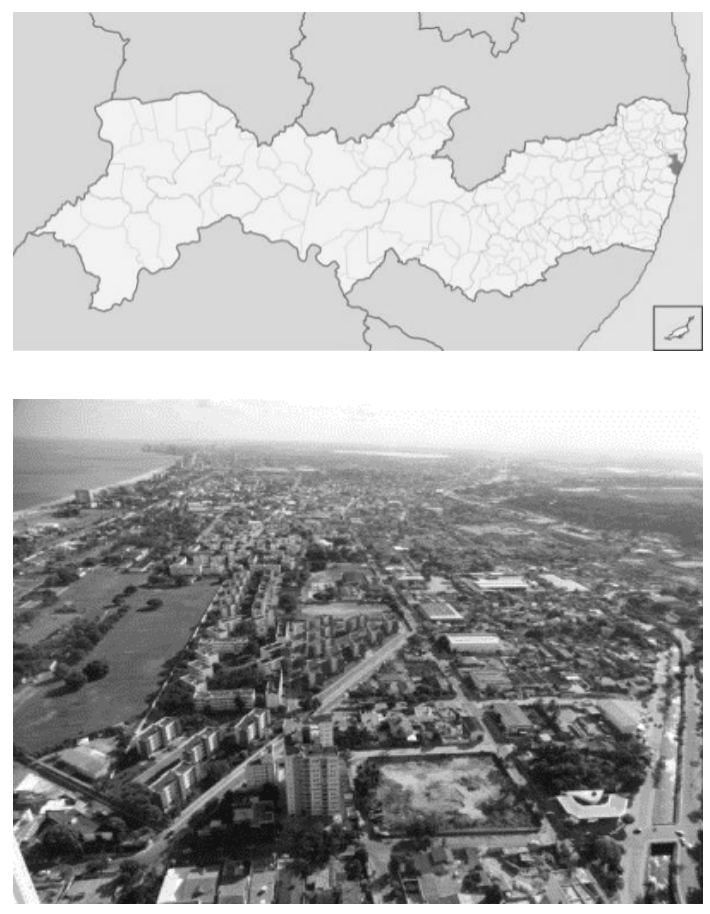

Figura 2. Recife - localização e imagem aérea (fonte: IBGE, 2010 e Acervo QUAPÁ-SEL, 2014).

\section{Maceió}

Maceió é capital do Estado de Alagoas e se localiza na Região Nordeste (Figura 3). Em 2014, a população era de 1.005. 319 habitantes, ocupando uma área de $510,655 \mathrm{~km}^{2}$, com densidade de 1.968,69 hab / km² e IDH: 0,735. Em 2011, o PIB / per capita era de R\$ 14.572,42 / US\$ 7.768,64 / $€ 5.986,53$. Em relação ao suporte físico, sua altitude varia entre 7 a $120 \mathrm{~m}$. O território é composto por tabuleiros, grotas, lagoas, dunas e praias, alagados e restingas, marcado pela presença dos Rios Mundaú e Paraíba do Meio. A vegetação apresenta a cobertura original de Mata Atlântica.

\section{Salvador}

Salvador é capital do Estado da Bahia e também se localiza na Região Nordeste (Figura 4). Em 2014, a população era de 2. 902927 habitantes, ocupando uma área de 693,276 km² com densidade de 4.187,26 hab. / km² e IDH: 0,759. Em 2012, o PIB / per capita era de R\$14.705,51 / US\$ 7.196,24 / $€ 5.455,78$. Em relação ao suporte físico, a altitude média é de $8,30 \mathrm{~m}$. O território é composto por planícies (cidade baixa); vales, escarpas e tabuleiros (cidade alta); alagados, lagoas e praias; dunas e restingas. A cobertura vegetal original era composta por Mata Atlântica.

\section{Vitória}

Vitória é capital do Estado do Espírito Santo e se situa na Região Sudeste (Figura 5). Em 2014, a população era de 352.104 habitantes, com área de $98,194 \mathrm{~km}^{2}$, densidade de $3.585,8$ hab. $/ \mathrm{km}^{2}$ e IDH de 0,845. Em 2010, o PIB / per capita era de R $\$ 76.721,66$ / US\$ $46.045,89$ / $€ 34.435,21$. Quanto ao suporte físico, a altitude média é de $12 \mathrm{~m}$. O território é composto por planície costeira, alagados, mangue, afloramento de morros isolados; parte insular e parte continental. O Maciço Central é um dos principais elementos estruturadores da paisagem e da ocupação, com morros de menor altura em seu entorno. A cobertura vegetal original era composta por Mata Atlântica.

\section{Santos}

A cidade de Santos se situa na Baixada Santista, na Região Sudeste (Figura 6). A Baixada Santista integra o complexo metropolitano expandido (megalópole do Sudeste), com cerca de 30 milhões de habitantes. Em 2014, a população era de 433.565 habitantes, com uma taxa de urbanização de 99,93\%, ocupando uma área de $280,674 \mathrm{~km}^{2}$, com densidade de $1.544,73$ hab. / km² e IDH de 0,840. Em 2012, o PIB / per capita era de R\$ 89. 898,17 / US\$ 43.992,25 / € 33.352,44. O suporte físico apresenta altitude de $2 \mathrm{~m}$, com território composto por planície costeira, alagados e manguezais com afloramento de morros isolados, apresentando parte insular e parte continental. A cobertura vegetal original era composta por Mata Atlântica.

\section{Padrões morfológicos e processo de produção das formas urbanas}

Os padrões morfológicos são neste artigo 

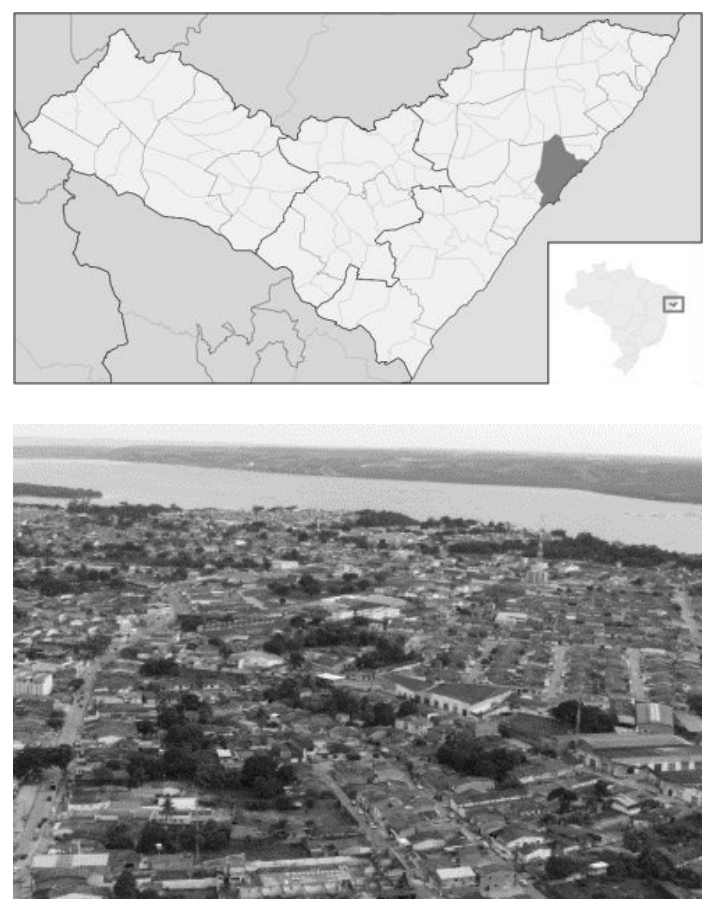

Figura 3. Maceió - localização e imagem aérea (fonte: IBGE, 2010 e Acervo QUAPÁ-SEL, 2014).
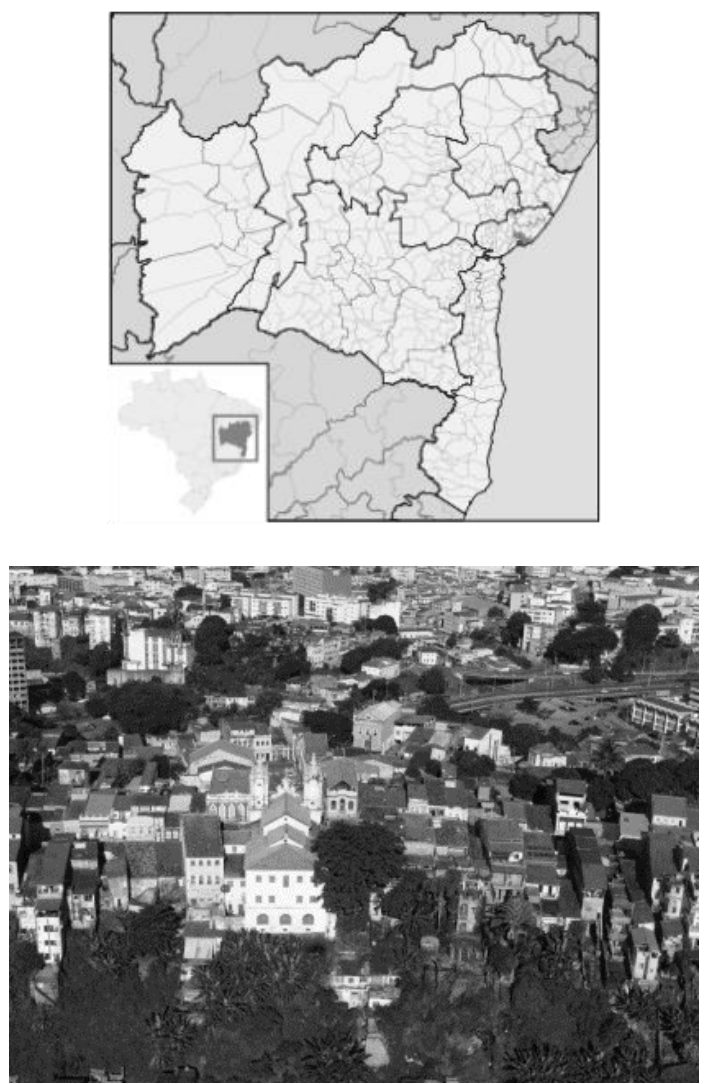

Figura 4. Salvador- localização e imagem aérea (fonte: IBGE, 2010 e Acervo QUAPÁSEL, 2014).
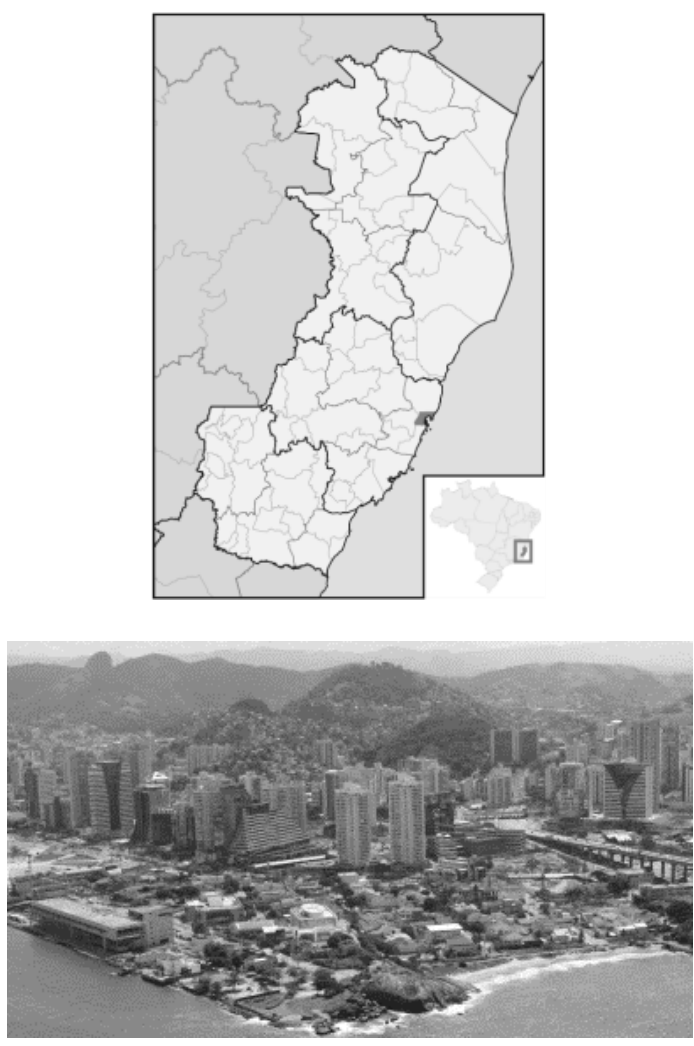

Figura 5. Vitória - localização e imagem aérea (fonte: IBGE, 2010 e Acervo QUAPÁ-SEL, 2014).
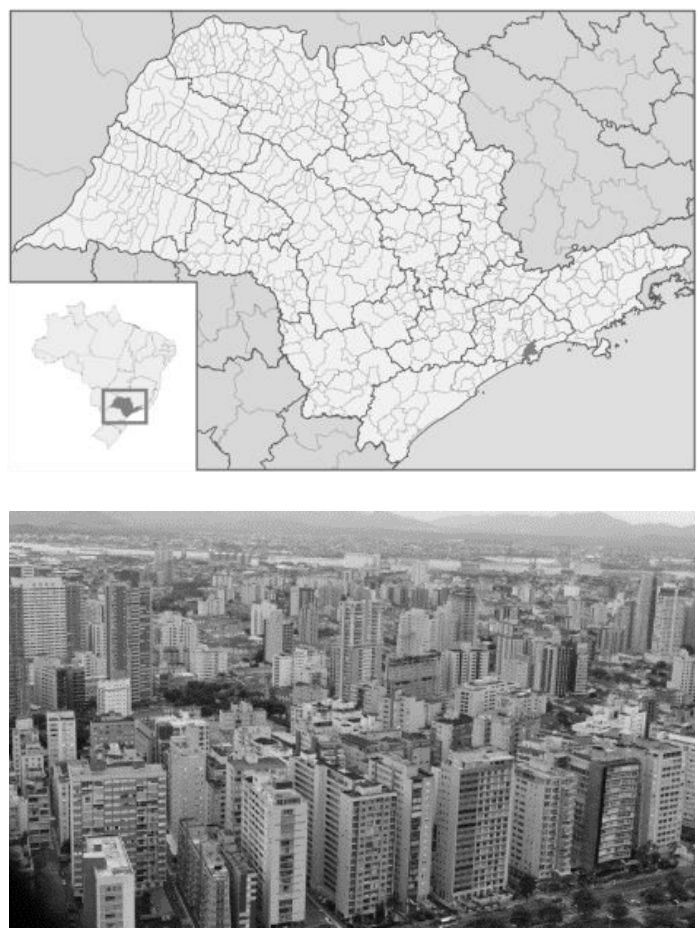

Figura 6. Santos - localização e imagem aérea (fonte: IBGE, 2010 e Acervo QUAPÁ-SEL, 2014). 
definidos como variações acerca de modelos constituídos, ditados por culturas e épocas diferentes e os tipos são manifestações incidentes que reúnem características distintas para um mesmo padrão (Tângari, 1999). Neste sentido, o estudo tipológico expressa a evolução da constituição da forma urbana e da paisagem construída e aponta as contradições dos processos de produção. Interessa-nos diferenciar, em particular, os distintos padrões morfológicos atualmente legíveis na realidade urbana das cidades analisadas. De um lado temos os padrões derivados das formas urbanas clássicas, cujas características podem, grosso modo, ser resumidas pela expressão da regularidade dos lotes e dos alinhamentos e pela clara definição entre espaço privado e espaço público, responsáveis pelas formas e funções urbanas ainda encontradas nos núcleos urbanos formados até meados do século XX (Figura 7).

De outro lado temos os padrões encontrados tanto nas transformações intraurbanas recentes, como também aqueles que observamos quando deixamos as áreas de urbanização consolidada e secular e adentramos os territórios de urbanização recente, dispersa com tecidos urbanos fragmentados. Nestas áreas a clareza em relação aos espaços livres privados e aos espaços livres públicos perde muito de seu sentido original (Figura 8).

Os elementos urbanos tradicionais, em especial a rua, são transformados em vias de acesso, perdem sua diversidade funcional e deixam de reunir o conjunto de características às quais estamos acostumados a associá-los. Neste novo ambiente as vias expressas tornaram-se a expressão máxima dessa nova especialização urbana: estabelecem conexões, garantem acessos e, mais do que isso, condicionam a ocupação do entorno e a utilização do espaço envolvente (Portas et al., 2011).

Trata-se de um ambiente polimórfico onde os padrões derivados desta urbanização recente, ocorrida nos últimos 40 anos, têm recebido por parte de diferentes autores, denominações distintas que respondem a um esforço de compreensão deste fenômeno (Portas et al., 2011). Para efeito desta análise reteremos para esta forma de urbanização recente a denominação urbano alargado (Secchi, 2009[2005]). Nas cidades analisadas, essas duas formas ou representações de cidade, até certo ponto antagônicas, ocorrem de forma associada, onde o sistema de espaços livres se apresenta através de formas, escalas e funções distintas (Figura 9).

O urbano alargado é uma realidade atual talvez de maiores dimensões do que a cidade tradicional quando se trata da quantidade de solo ocupado. Apesar disso, Carvalho (2003), num trabalho sobre forma urbana, afirma que tanto as representações quanto as ferramentas mais frequentes utilizadas para reduzir a complexidade urbana atual ainda carregam como referência os padrões encontrados na formação da cidade tradicional, utilizando-os mesmo quando se trata da cidade dispersa.

Se, como dissemos, na cidade consolidada e secular o sistema de espaços livres públicos é totalmente legível e passível de ser percorrido no sentido proposto por Certeau (2011[1984]), no urbano alargado das áreas de expansão recente outros elementos ganham importância e visibilidade. Além das grandes infraestruturas viárias, os espaços livres pertencentes ou associados à estrutura ecológica se expressam em outra escala, uma escala que se refere ao território e não apenas à cidade (Portas et al., 2011). Apesar da pouca importância relativa conferida a estas estruturas ambientais na organização do território, atualmente elas representam um dos elementos de maior expressividade quando se trata de espaços e de potencial estruturador da organização urbana. Isto é particularmente significativo nas cidades de Salvador e Recife (figuras 8 e 9).

Nesta análise, mesmo tendo como restrição os elementos fornecidos pelas oficinas realizadas, buscamos, através de um amplo levantamento fotográfico sobre todas as cidades analisadas, ir um pouco além das terminologias tradicionais e intencionalmente valorizar outros elementos mais característicos e representativos da urbanização contemporânea.

Faz-se necessário, portanto, entrar na descrição e diferenciação das formas concretas do tecido urbano e como ele se 


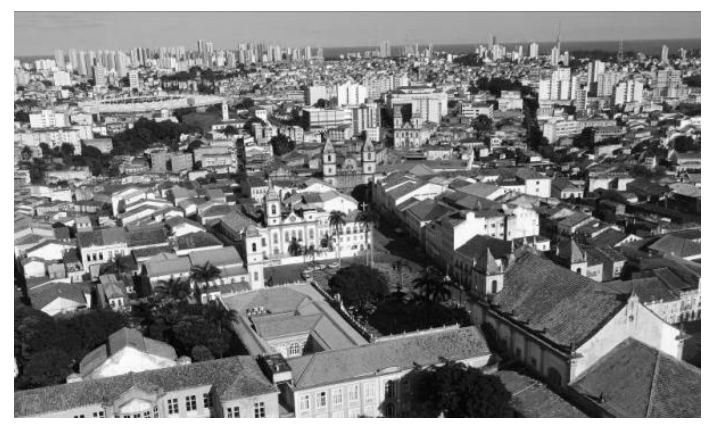

Figura 7. Salvador - área central: traçado regular com definição entre espaço privado e espaço público (fonte: QUAPÁ-SEL, 2014).

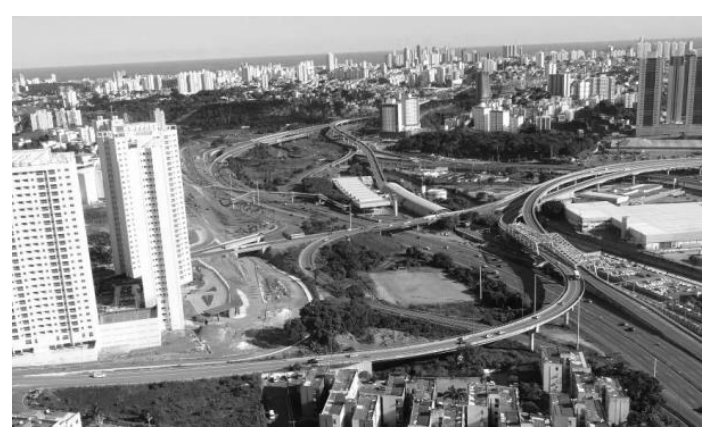

Figura 8. Salvador - área de expansão: estruturas viárias, reservas ambientais e novas ocupações (fonte: QUAPÁ-SEL, 2014).
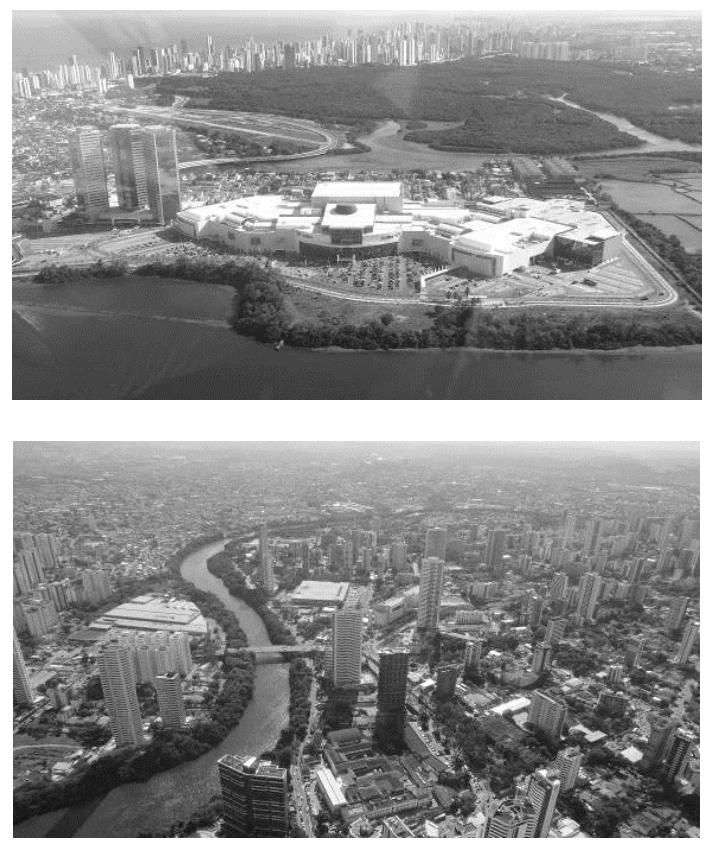

Figura 9. Recife: (a) tecido consolidado, estruturas ambientais; (b) tipos mistos com verticalização e grandes superfícies de comércio e serviços (fonte: QUAPÁ-SEL, 2014). apresenta de modo especifico em cada uma das cidades. Mais do que isso, é importante qualificar e diferenciar como cada uma das cidades responde a esse universo de forças que estão induzindo à dinâmica urbana atual. Para isso, buscamos destacar a fisiografia do tecido urbano e de seus componentes como quadras, lotes, edifícios e vegetação (Lamas, 1992; Tângari, 2013a) e os agentes e processos de produção da forma urbana, conforme discutidos em Silva e Lima (2014) e Parahyba (2014).

Descrevemos a seguir os padrões de tecido, os tipos morfológicos e os processos de produção da forma urbana identificados, onde observamos situações bastante heterogêneas, reunindo ocupações uni e multifamiliares com predominância de volumetria horizontal, à exceção de Santos, que apresenta historicamente um predomínio de volumetria verticalizada.

Alguns desses tipos se apresentam respeitando uma fisiografia mais tradicional de lote, quadra e continuidade urbana. Outros, mais comumente em situações de periferia ou mesmo dispersos no território induzidos pela dinâmica de expansão territorial associada às novas estruturas de mobilidade, se apresentam como conjuntos autônomos, seja de unidades unifamiliares ou multifamiliares, seja de superfícies concentradoras de comércio e serviços que se constituem em contenedores descritos por Solà-Morales (2002), procurando os locais de fácil acesso ao automóvel, e onde a cidade não segue modelo algum.

Recife

Quanto aos padrões morfológicos, trata-se de um tecido predominantemente horizontal e compacto nas áreas de ocupação mais tradicional da cidade. Em áreas ainda centrais, sujeitas às transformações recentes, verificam-se intensa verticalização e a ocorrência progressiva de conjuntos de edifícios e não apenas de edifícios isolados. Nota-se também a ocorrência de verticalização associada a grandes superfícies concentradoras de comércio e serviços, que se apresentam na paisagem como estruturas fechadas (contenedores). Nas áreas de expansão urbana observam-se tanto conjuntos isolados de residências 
unifamiliares, como também de multifamiliares verticalizados, ambos associados a novas estruturas de mobilidade (Figura 10). As ocupações de baixa renda estão localizadas, mais comumente, próximas a grotas, lagoas, restingas, e em conjuntos habitacionais situados no fundo do território e descolados da 'cidade', ou do direito à cidade.

Quanto aos tipos elencados: i) quadras com volumetria horizontal com e sem recuo, conjuntos habitacionais e condomínios horizontais de tipos variados; ii) quadras com volumetria vertical com e sem recuo, nas faixas de orla junto ao centro e no entorno, e tipos de quadra mistos; e iii) quadras fechadas de volumetria vertical com conjuntos de edifícios situados em áreas próximas às estruturas de mobilidade, tanto no centro como na periferia de alta renda; e iv) destacam-se a dimensão da ocupação informal como também a verticalização recente tanto na área central quanto a tendência de verticalização de áreas mais periféricas ligadas à alta renda.

Quanto ao processo de produção: i) vetores de desenvolvimento metropolitano em três direções - norte, sul e oeste, com intervenções localizadas, em sua maioria, fora da cidade; ii) densificação por verticalização ocorrendo preferencialmente ao longo dos eixos preferenciais de mobilidade; este adensamento ocorre também em situações de aparente indiferença quanto à localização, desde que garantida sua proximidade à rede que estrutura $\mathrm{o}$ contemporâneo das relações urbanas; iii) destacam-se as áreas de transformação do edificado - intra-urbanas - com conjuntos de edifícios localizados em proximidade com as redes de mobilidade diferenciada, também visíveis nas áreas de expansão urbana, acessadas por um novo sistema viário arterial e eventualmente associadas a grandes estruturas de comércio e serviços; em função do significado e da arquitetura desses empreendimentos periféricos, depreende-se que não se trata de expulsão da classe média das áreas centrais e sim de estratos de renda e emprego em condições de escolher novas formas e lugares para se posicionar na cidade; iv) verticalização recente associada ao aumento do coeficiente de aproveitamento definido pelos parâmetros da legislação; v) estruturas ambientais - sofrendo pressão de ocupação seja por parte dos setores associados ao capital imobiliário, seja por parte daqueles que procuram a qualquer custo se manter na cidade; estas estruturas (ou parte delas) não estão sendo minimamente consideradas para atuarem de forma ativa e estrutural na organização e qualificação do território; entretanto, as estruturas ambientais ainda se mostram com grande expressividade em escala regional; são atualmente os maiores espaços livres da paisagem urbanizada e ainda aparecem como fortes elementos de (con)tenção da urbanização; e vi) empreendimentos do Programa Minha Casa Minha Vida / MCMV na periferia; as áreas de ocupação informal e sua influência sobre espaços livres e forma urbana.

\section{Maceió}

Quanto aos padrões morfológicos trata-se de um tecido predominantemente horizontal e descontínuo; compacto nas áreas de ocupação tradicional, com edificações no alinhamento e verticalização moderada mais próxima à orla. Nas áreas de expansão urbana ocorrem tanto a incidência de conjuntos habitacionais verticalizados de médio padrão, situados nos tabuleiros em continuidade à ocupação, como também conjuntos de habitações unifamiliares situados no fundo do território e de urbanização descontínua. Habitações informais se localizam nos interstícios e nas grotas abaixo dos tabuleiros (Figura 11).

Quanto aos tipos elencados: i) quadras com volumetria vertical, sobre tabuleiros e na orla marítima, com e sem recuo; ii) quadras com volumetria horizontal e ocupação informal; iii) quadras e empreendimentos fechados com conjuntos de edifícios de médio padrão; iv) empreendimentos do MCMV nas áreas de expansão urbana; e v) processo de verticalização recente devido ao aumento do coeficiente de aproveitamento pelos novos parâmetros da legislação, incidente nas áreas próximas à orla e dentro dos limites da cidade tradicional. 

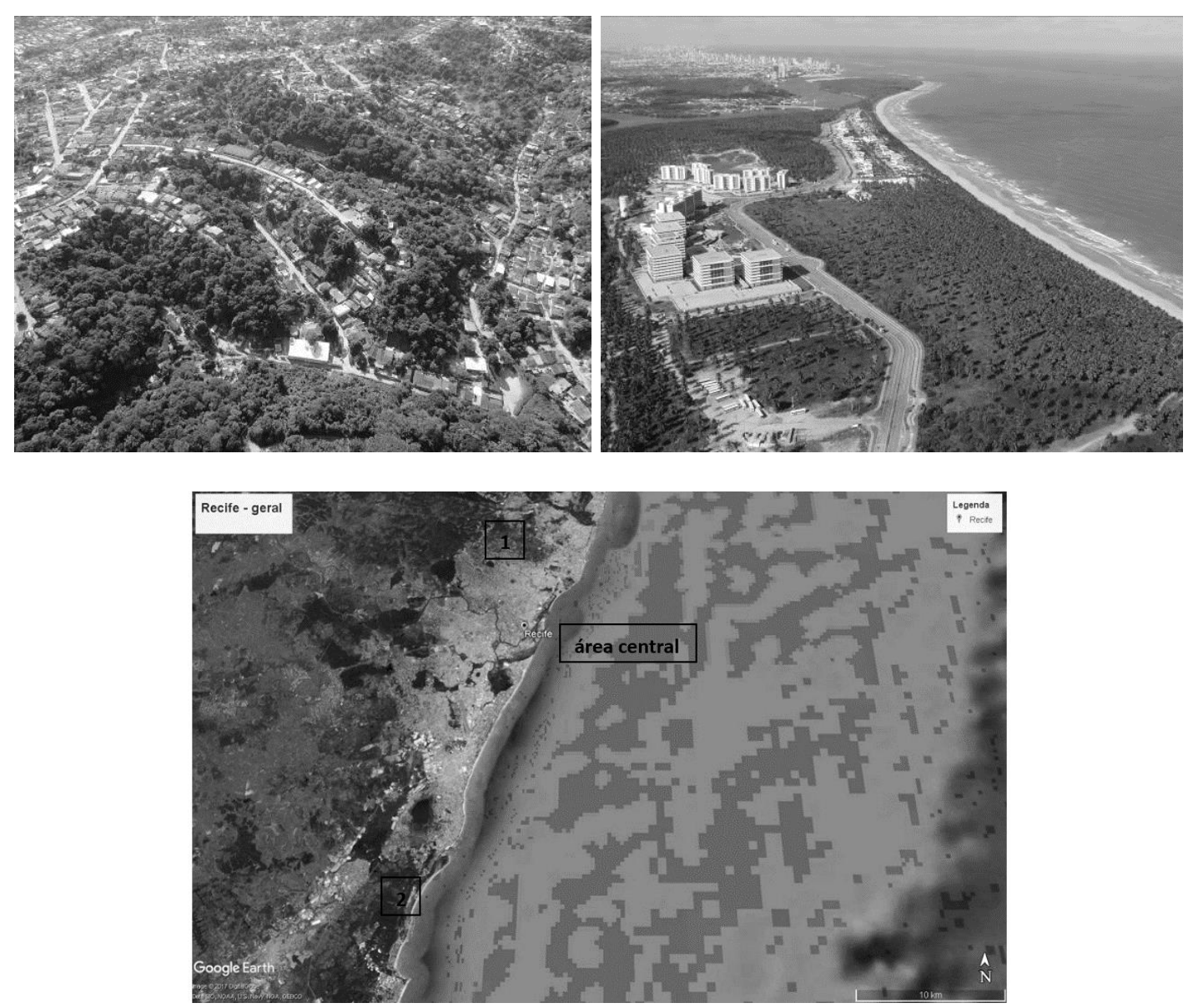

Figura 10. Recife:

a) grotas ocupadas junto a áreas centrais; b) contenedores em áreas de expansão urbana;

c) ocupação em grotas (a), contenedores em áreas de expansão (b)

(fonte: QUAPÁ-SEL, 2014; elaborado pelos autores sobre base do Google Earth, 2017).

Quanto ao processo de produção: i) novos empreendimentos viários viabilizando a expansão urbana e pouca contrapartida na expansão do transporte público; ii) adensamento promovido pelo setor imobiliário com verticalização moderada quando comparado a outras capitais (Recife, Salvador, Vitória); iii) interesses do mercado imobiliário conduzindo novas áreas e formas de expansão; iv) investimentos do governo federal em empreendimentos do Programa MCMV; v) pressão sobre as estruturas ambientais, mais visíveis quando associadas aos diversos tipos de empreendimentos MCMV do que ligados ao mercado imobiliário; vi) o sistema ecológico, também de significativa expressividade no que tem de contínuo e estrutural, não tem sido observado na expansão e ordenamento do território; e vii) ocupação informal nos grotões.

\section{Salvador}

Quanto aos padrões morfológicos trata-se de um tecido predominantemente horizontal e descontínuo; compacto e com construções definindo alinhamentos em toda área central e mais tradicional da cidade; intensa transformação e verticalização nas áreas centrais mais próximas à orla e nas áreas no entorno das novas infraestruturas viárias de fundo de vale. É visível a ocorrência de grandes superfícies de comércio e serviços em vazios remanescentes ou transformações de uso original.

Tanto nas áreas intra-urbanas em 

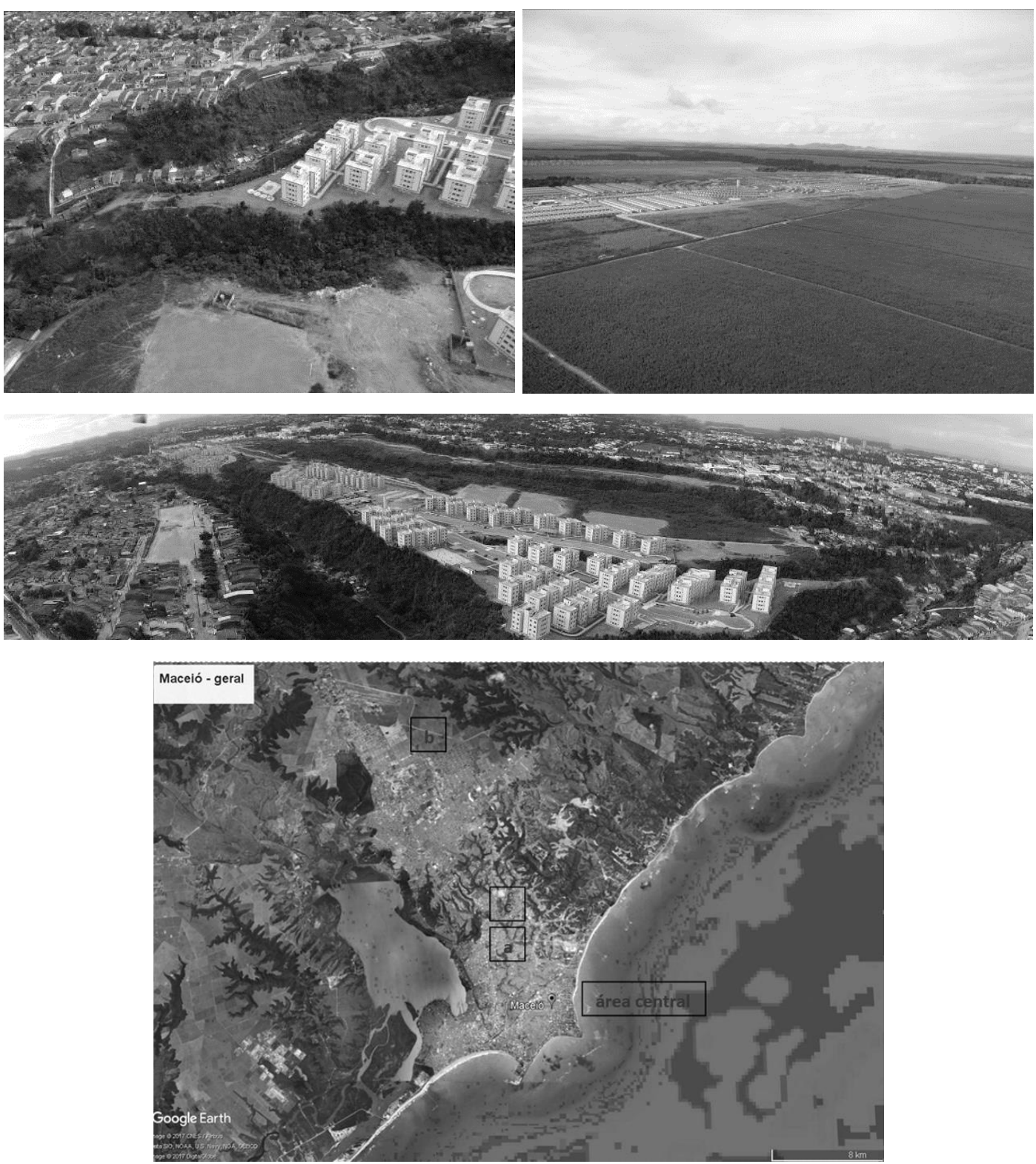

Figura 11. Maceió:

a) tecido horizontal junto a conjuntos habitacionais verticalizados de médio padrão;

b) habitações unifamiliares situadas no fundo do território;

c) tecido predominantemente horizontal e descontínuo;

d) tecido horizontal junto a conjuntos habitacionais $(a)$, habitações unifamiliares no fundo do território $(b)$, tecido predominantemente horizontal e descontínuo $(c)$

(fonte: QUAPÁ-SEL, 2014; elaborado pelos autores sobre base do Google Earth, 2017).

transformação como nas áreas de expansão urbana observa-se a verticalização a partir de edificações isoladas, entretanto, é cada vez mais visível a presença de conjuntos de edifícios com 25 andares ou mais associados às novas estruturas de mobilidade. As ocupações de baixa renda ocuparam tradicionalmente as partes mais altas dos morros em áreas mais distantes do centro e da orla. Os novos conjuntos habitacionais uni e multifamiliares aparecem aumentando a pressão sobre as áreas de preservação e descolados da continuidade urbana (Figura 12).

Quanto aos tipos elencados: i) quadras com ocupação e forma urbana vertical 

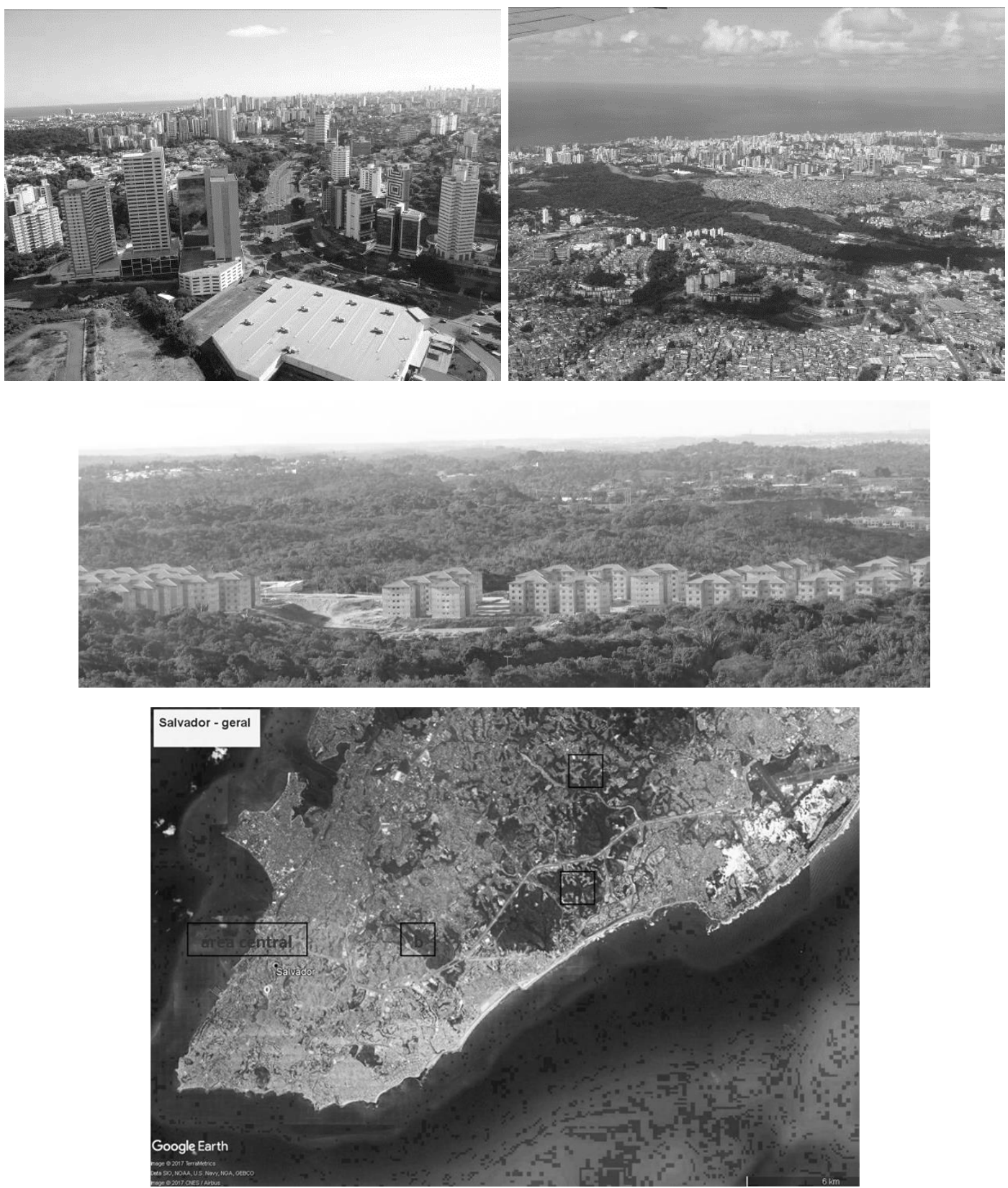

Figura 12. Salvador:

a) verticalização junto a novas estruturas viárias;

b) estruturas ambientais e ocupação tradicional dos morros distantes da orla;

c) conjuntos habitacionais junto a áreas de preservação;

d) verticalização junto a novas estruturas viárias $(a)$, estruturas ambientais e ocupação tradicional de morros $(b)$, conjuntos habitacionais junto a áreas de preservação $(c)$

(fonte: QUAPÁ-SEL, 2014; elaborado pelos autores sobre base do Google Earth, 2017).

heterogênea com e sem recuo; prédios mais antigos situados na parte de formação tradicional da cidade, variando entre cinco e dez andares, em geral sem recuos e definindo alinhamentos contínuos e regulares; verticalização mais recente, em geral, com edifícios implantados com recuos, isolados ou em conjuntos, com mais de 25 andares; ii) grandes superfícies de uso comercial e de serviços, contenedores; iii) quadras com 
ocupação horizontal: casas sem recuos nas escarpas, vales e tabuleiros; iv) quadras com ocupação informal nas encostas longe da infraestrutura e nas áreas intersticiais de interesse ambiental; v) extensas estruturas viárias determinando a ocupação por setores autônomos sem unidade e continuidade visível; e vi) conjuntos habitacionais, unifamiliares e multifamiliares, implantados predominantemente nas áreas de expansão urbana.

Quanto ao processo de produção: i) Salvador traz um exemplo bastante característico da importância fundamental da associação entre os diferentes agentes públicos e privados, e de como estes investimentos são decisivos na condução/indução dos processos de transformação e expansão da forma urbana; ii) os investimentos dos Governos Estadual e Municipal para ampliação das redes de infraestrutura e transporte, nos interstícios do tecido urbanizado e fundos de vale, podem ser considerados como os grandes indutores das transformações atuais do tecido urbano; iii) densificação e verticalização ocorrem predominantemente ao longo dos eixos preferenciais de mobilidade: são bastante visíveis e legíveis as avenidas de fundo de vale e principalmente a Avenida Paralela, construída na primeira metade dos anos 1970, ligando a parte tradicional de Salvador ao aeroporto; iv) estruturas ambientais excetuando a parte histórica da cidade e a orla, mais densamente ocupada e sem vazios significativos -, observam-se na escala regional áreas expressivas de preservação, compostas por uma ampla paisagem vegetada, lagoas, dunas e restingas; v) nas áreas onde foram implantadas vias estruturais de mobilidade é grande a pressão de ocupação, por parte do setor imobiliário formal e por aqueles que procuram um lugar na cidade a qualquer custo; vi) na relação do urbano com as estruturas ambientais, verifica-se uma ausência quase total da associação destas a qualquer forma de organização territorial; vii) verticalização recente e aumento do coeficiente de aproveitamento devido a mudanças na legislação urbanística; e viii) investimentos da Prefeitura e do Governo Federal com Programa MCMV.

\section{Vitória}

Quanto aos padrões morfológicos trata-se de um tecido predominantemente horizontal e descontínuo, fortemente condicionado pelo caráter insular e pelas estruturas ambientais. Tecido compacto nas áreas mais centrais, seguindo a forma da cidade tradicional de lotes, quadras e as construções definindo alinhamentos precisos. Verticalização de baixo gabarito (cinco andares) na área do Plano do Arrabalde. Verticalização homogênea e de médio gabarito na faixa litorânea das praias.

Nas áreas próximas ao centro, os processos de transformação intra-urbana mostram-se mais intensos, produzindo forte substituição do edificado e verticalização associada às novas acessibilidades. Tipologia heterogênea onde é visível tanto o edifício isolado com 25 andares ou mais, como conjuntos de edifícios em um mesmo lote / quadra, incidindo também ocorrência de grandes superfícies autônomas de comércio e serviços (Figura 13).

Quanto aos tipos elencados: i) quadras oriundas do Plano do Novo Arrabalde, de Saturnino de Brito, 1896, com edifícios de cinco a seis andares; ii) quadras horizontais e verticais com espaços edificados em forma contínua; iii) quadras com heterogeneidade na forma urbana vertical: prédios com cinco e com mais de 25 andares; iv) quadras com áreas significativas de padrões horizontais; v) quadras em processo de verticalização da orla para o interior da área urbanizada e na base das encostas dos morros; vi) quadras com ocupação informal nas encostas dos morros; e vii) empreendimentos do MCMV sem visibilidade na paisagem.

Quanto ao processo de produção: i) investimentos do Governo Estadual e Governo Municipal para ampliação das redes de infraestrutura e de transporte; ii) investimentos do Governo Federal e de grandes indústrias com extensas glebas reservadas a portos, ferrovias e instalações industriais (Figura 14); iii) verticalização e adensamento em áreas de interesses do mercado, viabilizadas pelos sistemas de infraestruturas de mobilidade diferenciada e associadas a novas estruturas de comércio e 

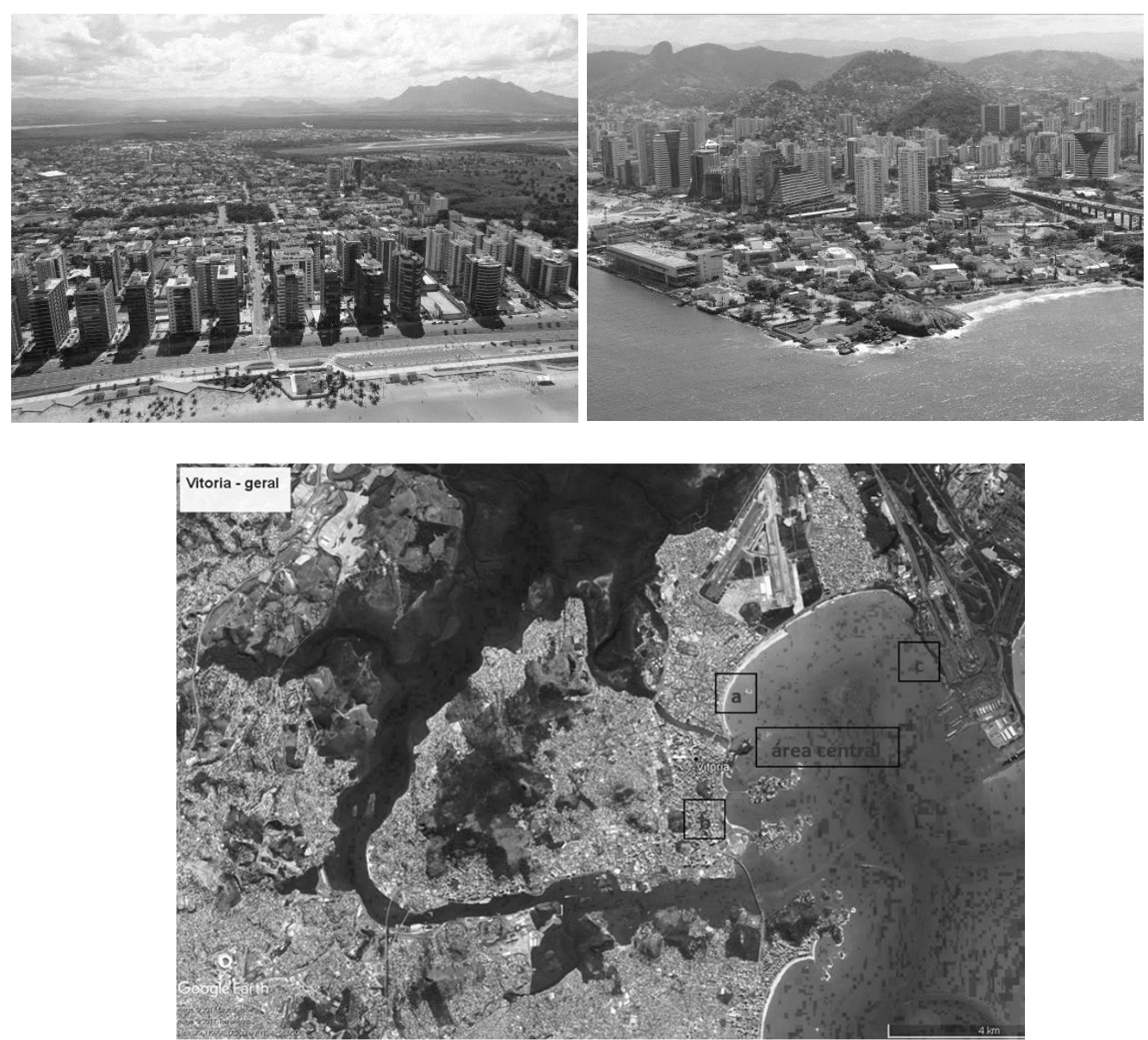

Figura 13. Vitória:

a) verticalização na orla em Camburi;

b) ocupação dos morros que entremeiam o tecido urbano;

c) verticalização na orla em Camburi $(a)$, ocupação dos morros $(b)$, infraestrutura ferroviária e portuária $(c)$

(fonte: QUAPÁ-SEL, 2014; elaborado pelos autores sobre base do Google Earth, 2017).

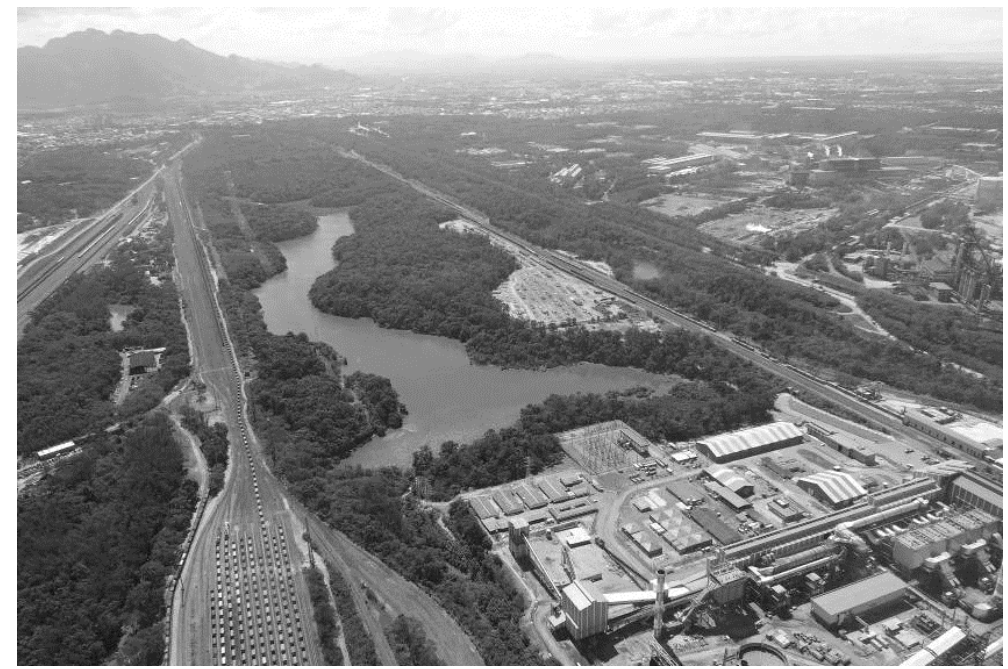

Figura 14. Vitória, infraestrutura ferroviária e portuária mesclada a áreas de preservação (fonte: QUAPÁ-SEL, 2014). 
serviços; iv) terra urbana de oferta restrita em função das características do sítio insular / continental e áreas protegidas - e alta valorização do solo urbano; v) estruturas ambientais - a característica insular / continental é forte condicionadora da ocupação urbana, pois o afloramento de morros isolados e mais especificamente o maciço central despontam como um dos principais elementos estruturadores da paisagem e da ocupação; vi) observa-se forte pressão sobre as estruturas ambientais, seja por parte do mercado formal, seja por parte do mercado informal; vii) quanto aos morros isolados, um elemento forte na paisagem local, alguns foram parcialmente destruídos e utilizados para aterramento de outras áreas, outros estão em processo de envelopamento pelas edificações verticais em seu entorno; viii) a cidade sobe os morros tanto com edificações do setor imobiliário formal, quanto com ocupações informais; ix) as planícies inundáveis, apesar de em boa parte protegidas pela legislação, também estão sob pressão de ocupação; x) ocorre baixa incidência de Habitação de Interesse Social (MCMV) com população de baixa renda deslocada para os morros e outras cidades da região metropolitana; e xi) verticalização recente e aumento do coeficiente de aproveitamento devido a mudanças na legislação urbanística.

\section{Santos}

Quanto aos padrões morfológicos, trata-se de um tecido densamente ocupado, verticalizado e contínuo, definido pelo seu caráter insular e pelas estruturas ambientais (mangue e morros): i) quadras oriundas do Plano de Saturnino de Brito, de 1914, a partir de traçado com canais de drenagem e definição de quadras e lotes; ii) quadras da orla marítima, ocupação tradicional, homogêneas em sua verticalização - doze a quinze andares; iii) quadras nas partes internas da ilha: verticalização recente e heterogênea, prédios com cinco, doze a quinze e com mais de 25 andares; iv) quadras com residências horizontais e recuos; e v) ocupação da orla tradicional da cidade como um bom exemplo de espaço público e verticalização (Figura 15).

Quanto ao processo de produção: i) terra urbana de oferta restrita devido à ocupação consolidada e às características do sítio (ilha, mangues e morros), impondo elevados valores para o solo urbano; ii) investimentos do Governo Estadual e Governo Municipal para ampliação das redes de infraestrutura e de transporte; iii) articulação viária metropolitana com dois túneis: Túnel Maciço Central - Santos / São Vicente (Governo Estadual) - e Túnel Submerso - Santos / Guarujá / Vicente de Carvalho (Governo Estadual) - que transforma a acessibilidade de várias áreas da cidade situadas na área de influência dessa nova infraestrutura; iv) implantação do sistema de trem VLT (Governo do Estado) traz, do ponto de vista da acessibilidade peatonal, possibilidades bastante concretas de se trabalhar com o adensamento das áreas do entorno; v) investimentos em gás e petróleo geram nova dinâmica urbana e novas demandas de área construída para habitação e comércio; vi) estruturas ambientais - em função da ocupação quase total da ilha e de sua parte continental, além da orla e dos morros isolados - são de pouca expressividade quando comparadas a outras cidades costeiras; vii) a pressão de ocupação foi em parte exportada para outras cidades da região metropolitana e, em parte, está se expandindo para algumas áreas de terrain vague e transformando o edificado original com edifícios de maior altura e maior coeficiente de aproveitamento em áreas onde a legislação tornou essa mudança possível; viii) decorrente da restrição de terras e do alto valor do solo, praticamente inexistem ações concretas construídas ou previstas destinadas à Habitação de Interesse Social (MCMV) e a população de baixa renda se desloca para os morros e outras cidades da região metropolitana; ix) verticalização e adensamento em áreas de interesse do mercado; e x) aumento do coeficiente de aproveitamento aprovado em 2005. 

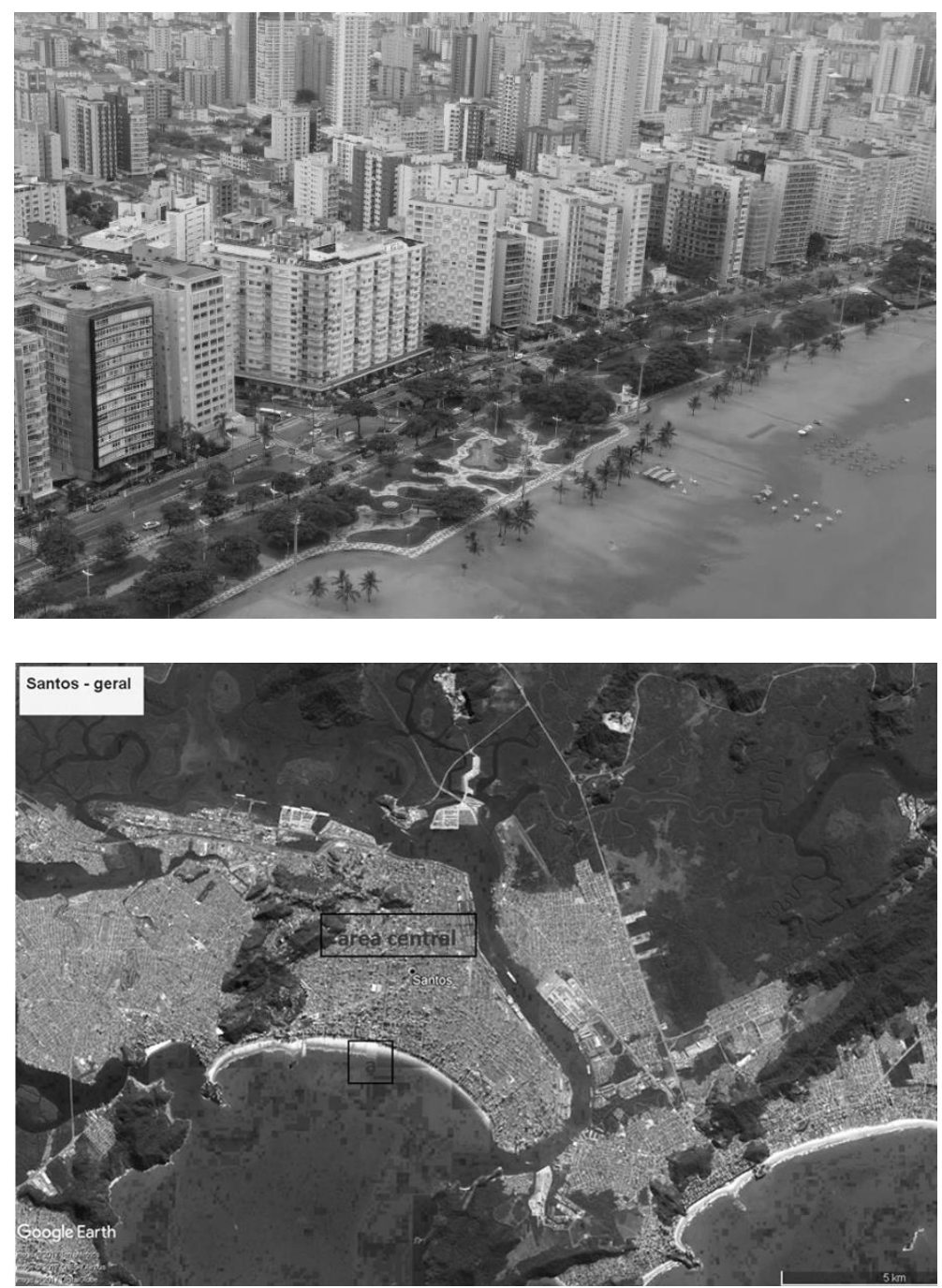

Figura 15. Santos:

a) ocupação da orla tradicional com espaço público;

b) ocupação verticalizada na orla

(fonte: QUAPÁ-SEL, 2014, elaborado pelos autores sobre base do Google Earth, 2017).

Espaços livres e forma urbana: transformações no urbano consolidado e no urbano alargado

Um dos objetivos deste artigo nos coloca no propósito de atualizar a discussão sobre as relações entre o sistema de espaços livres e a forma urbana. Uma de nossas hipóteses estabelece que as novas infraestruturas, os novos sistemas de mobilidade e as estruturas ambientais constituem as principais forças definidoras das novas cartografias urbanas (Portas et al., 2007). Neste ambiente, seja ele de transformações intra-urbanas no tecido urbano consolidado, seja de conformação do tecido urbano alargado, ganham importância os diferentes agentes e processos de produção que ocorrem associados aos investimentos públicos e privados, em planos, projetos e obras. Marcam de forma decisiva os processos de mudanças no tecido existente e na indução de diferentes formas de expansão urbana.

As novas infraestruturas que asseguram a mobilidade e o funcionamento do território têm sido, em boa parte dos casos tratados neste trabalho, definidas por autoridades situadas em níveis superiores ao do município (Governo Federal, Governo Estadual e Grandes Empresas que de alguma 
forma estão associadas à provisão de infraestrutura - setores de transporte, energia, mineração, etc.). Esses atores tem grande autonomia decisória em relação ao município e são regidos por lógicas e interesses próprios. Isto faz com que parte das infraestruturas, que atualmente asseguram a ocupação de partes amplas do território, esteja em grande medida, descoladas ou pouco articuladas com a administração local (Portas et al., 2007). Estes fatos são mais facilmente perceptíveis quando se analisam as várias categorias de obras viárias e de transporte, mas ocorrem igualmente em outras situações em aparência distantes, mas cujas atividades e decisões afetam diretamente os interesses locais. É o caso, entre outros, da localização de novas atividades portuárias e da implantação de atividades ligadas a petróleo e energia.

As decisões de implantação do transporte urbano na cidade de Salvador, por exemplo, tanto no que concerne a mobilidade 'quase exclusiva' para automóveis (as muitas avenidas expressas de fundo de vale e, muito especialmente, a Avenida Paralela, responsável pela expansão urbana em direção ao aeroporto), como no que diz respeito ao transporte de passageiros (o metrô de Salvador), remetem a obras cuja decisão e implantação se condiciona a estratégias setoriais ligadas ao governo estadual, ao governo federal, à indústria automobilística, etc. Ainda com relação à Av Paralela, o Governo do Estado não responde apenas pela construção da infraestrutura, mas colabora também transferindo toda sua administração para áreas ao longo desta avenida, contribuindo tanto para o desenvolvimento desta parte nova da cidade como para o esvaziamento da área central, onde originalmente estavam localizadas as funções de administração e representação.

No caso de Santos, uma cidade mais compacta, densamente ocupada e com poucos terrenos ainda disponíveis para urbanização ou para (re)ocupação, esta mesma forma de intervenção ocorre a partir da implantação de túneis e do transporte de passageiros de média capacidade - VLT. Essas obras são definidas pelo Governo do Estado e que tem viabilizado a (re)urbanização de áreas centrais ou mesmo periféricas. Ainda no caso de Santos, as decisões das grandes empresas de gás e petróleo demandam, por um lado, novas infraestruturas e, por outro lado, propulsionam a dinâmica urbana. Quando atuam no sentido da relocação de atividades, algumas dessas empresas produzem no espaço urbano o vazio, o terrain vague (Solà-Morales, 2002) ou a tiers paysage (Clément, 2003), que correspondem a áreas de ocupação industrial ou de grandes equipamentos que se tornaram obsoletas. Atualmente algumas dessas áreas estão sendo objeto de transformação do edificado e de verticalização, utilizando os novos coeficientes de aproveitamento aprovados pela legislação urbanística.

Este descolamento entre o nível local e os níveis decisórios superiores também é perceptível quando se observam as grandes urbanizações de caráter popular, promovidas pelo governo federal através do programa MCMV e encontradas em praticamente todas as cidades analisadas. Estas operações, via de regra, têm sua localização em flagrante descontinuidade com a cidade existente, promovendo o alargamento da ocupação para áreas descontinuas e dispersas. Apesar de muitos desses empreendimentos serem formalmente abertos, a exemplo dos loteamentos fechados, esses conjuntos habitacionais também se inserem como peças autônomas no fundo do território, como pode ser especialmente observado em Maceió e Salvador.

Portanto, a forma do urbano alargado está associada tanto à ação de atores privados como de atores públicos, vale tanto para a urbanização promovida pelos setores hegemônicos do capital imobiliário, como para as intervenções de caráter e promoção pública, seja na implantação de infraestruturas, seja nas implantações de habitação de interesse social do programa MCMV.

Numa abordagem inicial, a partir de considerações genéricas que nos traz a literatura sobre urbanização contemporânea, os efeitos desta sobre o que denominamos urbano alargado estariam, em grande parte, restritos a operações urbanas situadas na periferia. Isto em parte pode ser explicado pelo fato de a literatura sobre o tema, 
principalmente a de origem europeia, tratar de cidades mais consolidadas e sujeitas a legislações mais rígidas e seculares. Difícil imaginar, por exemplo, Paris com a permissividade da legislação urbana de Recife dos anos 2000 em relação aos novos 'arranha-céus'. Isto já ocorreu muito timidamente em Paris por um curto período, no final dos anos 1960 e nos anos 1970 e, mais recentemente, com um ou outro fato episódico. Um pouco mais podemos verificar na cidade de Londres dos anos 1980, mas é muito difícil encontrar essa liberalidade generalizada que percebemos na cidade de Recife.

$\mathrm{Na}$ análise das cidades em questão, respeitadas as diferenças entre elas, percebemos outra complexidade de transformações e de lugares que não se restringem às situações de baixa densidade, descontinuidade e dispersão urbana. Nessas cidades, especificamente, as transformações não ocorrem apenas no urbano alargado, nas periferias, mas igualmente nas áreas intraurbanas influenciadas pelos novos eixos preferenciais de mobilidade. Não ocorrem apenas de forma extensiva e de baixa densidade, nas situações onde a infraestrutura homogeneíza o território, mas igualmente de forma intensiva e de alta densidade, principalmente nas áreas já urbanizadas em que se oberva transformação com adensamento e verticalização do edificado.

O adensamento e a verticalização ocorrem também em situações de aparente indiferença quanto à localização desde que preservadas mínimas condições de acessibilidades às redes relacionais contemporâneas (Ascher, 2010 [2001]). A potência deste conjunto de situações, sejam elas no tecido intra-urbano consolidado ou no urbano alargado, apresenta maior visibilidade e incide particularmente nas cidades de Recife (Figura 16), Salvador, Vitória e, em menor escala, na cidade de Santos. Na cidade de Maceió, a menor das cidades analisadas, a verticalização é menos intensa e sua relação (ou não) com as redes relacionais ocorre apenas ocasionalmente.

Em termos tipológicos, encontramos a ocorrência de verticalização a partir de edifícios isolados, mas é cada vez mais frequente a verticalização a partir de conjuntos de edifícios em um mesmo lote / quadra. Nota-se também a ocorrência de verticalização associada à existência de grandes estruturas polarizadoras de comércio e serviços que se apresentam na paisagem como unidades autônomas, contenedores (Solà-Morales, 2002).

Entretanto, o tecido urbano alargado que encontramos nessas cidades não deve ser apressadamente associado apenas à baixa densidade. Este ambiente periférico é também povoado por conjuntos autônomos verticalizados e de densidade elevada, sempre associados a estruturas preferenciais de mobilidade. O modo como essas operações se implantam e desenham este território urbanizado mais amplo caracterizase por uma adição de fragmentos separados uns dos outros e, em seu entremeio, um conjunto de espaços livres tanto expressivos quanto imprecisos, composto por áreas de infraestruturas, reserva ambiental ou de mercado.

As situações descritas acima são particularmente visíveis nas cidades atualmente submetidas a fortes processos de transformação interna e também nos processos denominados aqui de 'urbanização alargada'. As cidades de Recife, Maceió e Salvador, em função das características geofísicas do território, exemplificam de modo claro essas transformações da forma urbana, tanto nas áreas mais centrais quanto no tecido urbano alargado.

Em Salvador, por conta da ocupação anterior ocorrida até os anos 1970, parte significativa dos fundos de vale foi preservada de ocupação. Nessa cidade, observa-se que nas partes altas das áreas mais estruturadas situam-se as faixas de população com renda média e média alta, nas encostas e nos tabuleiros mais distantes do centro e da orla, localiza-se a população de menor poder aquisitivo. Nos últimos 40 anos a cidade vem passando por transformações profundas com relação às infraestruturas de mobilidade, ocupando os fundos de vale com vias e avenidas expressas. Ao longo desses novos sistemas de mobilidade, tanto nas áreas intra-urbanas de ocupação mais antiga, como nas áreas de expansão urbana, incidem conjuntos de edifícios com 25 pavimentos ou 


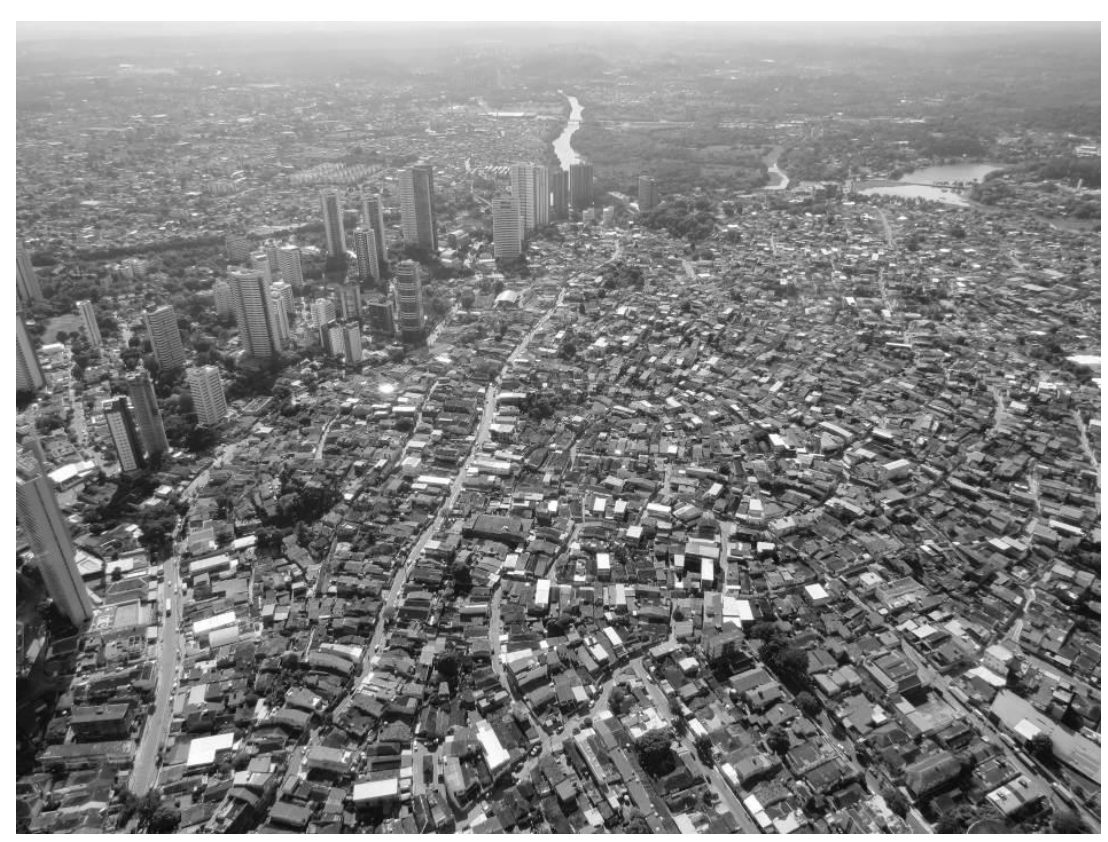

Figura 16. Recife - ocupação informal e verticalização descolada das principais estruturas de mobilidade (fonte: QUAPÁ-SEL, 2014).

mais, sendo que várias destas operações recentes estão associadas aos contenedores comerciais e de serviços.

Recife, a seu modo, responde a essas transformações associadas aos sistemas de mobilidade com uma das verticalizações mais extravagantes do Brasil, seja de edifícios isolados, seja de conjuntos de edifícios associados aos contenedores comerciais e de serviços (Figura 17). Também no tecido urbano alargado, Recife oferece exemplos tanto de expansão horizontal, como de verticalização periférica.

Maceió, em menor escala, também vem promovendo uma ocupação nos topos dos tabuleiros e estendendo a área urbanizada nas partes menos acidentadas. Neste caso, até mesmo em função da escala da cidade, os empreendimentos do MCMV são mais visíveis, e sua localização é autônoma até mesmo em relação às infraestruturas.

A avaliação deste programa realizado pela Rede Cidade e Moradia afirma que 'se o programa passou a atingir camada da população historicamente não atendida na área habitacional, não interferiu no seu lugar histórico nas cidades, reproduzindo o padrão periférico' (Jornal Valor Econômico, 10/02/15). Esta avaliação do programa reforça a ideia de que o padrão periférico do tecido urbano alargado é reproduzido e ampliado tanto pelas ações do Estado como pelo setor imobiliário formal. Fora do programa MCMV a população de baixa renda vem ocupando as grotas deixadas pela urbanização como vazios de interesse ambiental.

As cidades de Santos e Vitória, por estarem em parte contidas em ilhas ou envolvidas por mangues e áreas de interesse portuário, apresentam oferta de terras bastante restrita para novas ocupações. Devido a esse fato têm exportado sua população mais pobre para os morros e para as outras cidades de suas respectivas regiões metropolitanas.

Nestas duas cidades, mesmo os empreendimentos do programa MCMV tem influência muito restrita em função do valor do solo e da dimensão dos terrenos disponíveis. Por ser a mais densa e verticalizada das cidades analisadas, em Santos as transformações intra-urbanas são de menor incidência e visibilidade (Figura 18). Já em Vitória a dinâmica de transformação é mais forte e a pressão sobre as estruturas ambientais é bem mais visível. A cidade sobe os morros tanto através de edificações do mercado formal quanto das ocupações informais (Figura 19). 

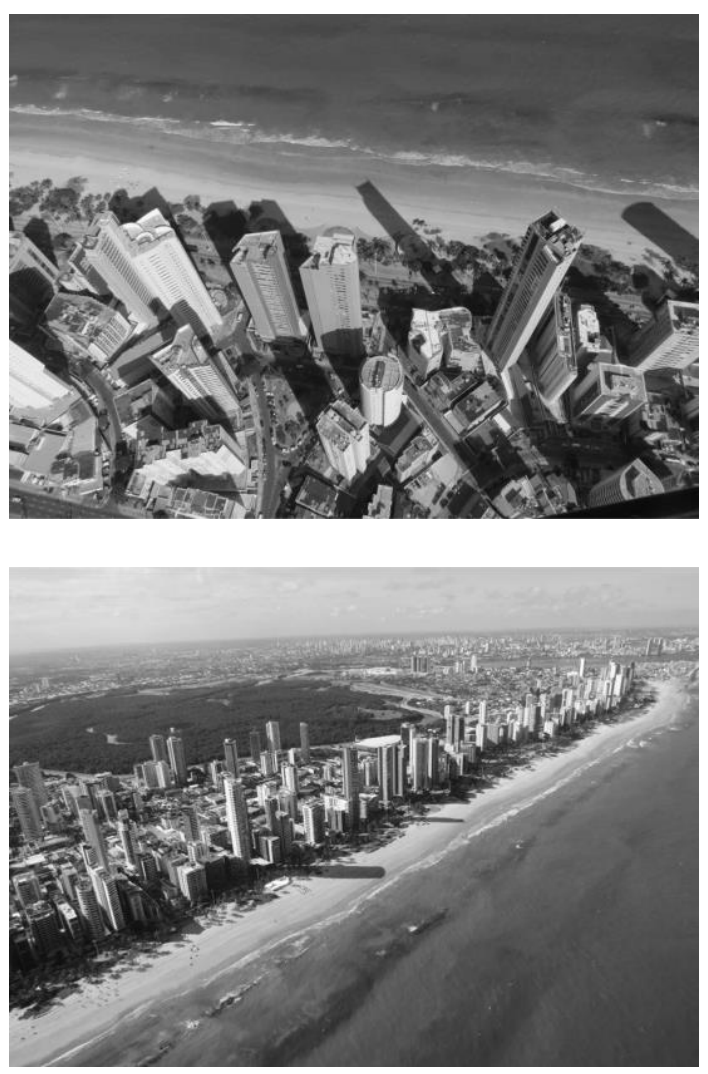

Figura 17. Recife - verticalização junto à orla (fonte: QUAPÁ-SEL, 2014).

No caso das cidades analisadas, cada uma a seu modo, as estruturas ambientais são fortes condicionadores da ocupação urbana. Uma grande diferença quando passamos da cidade secular, formada até meados do século XX, para o urbano alargado dos anos 2000, é que as estruturas ambientais ganham uma importância e uma expressividade nunca vistas. A esse respeito Ignasi SolàMorales, tratando da representação da cidade e da forma urbana, afirma que a sustitución de las vistas y perspectivas de la gran ciudad por imágenes aéreas está ligada directamente a su condition fragmentária, extendida por um território solo abarcable desde unos puntos de vista situados fuera de la mirada convencional (Solà-Morales, 2002, p. 67). Da mesma forma, quando adentramos esse universo amplo e fragmentado, a clareza com que definimos e trabalhamos os espaços livres e espaços públicos da cidade tradicional é substituída por uma nova relação entre espaços, surgindo um universo de indeterminações, o semi-público (ou semi-privado), as novas articulações dentro e fora. Temos as estruturas viárias, as áreas urbanizadas, às vezes contínuas e às vezes representadas por unidades autônomas, os vazios indefinidos entre elas e, marcando especialmente a paisagem, as massas contínuas representando as estruturas ambientais, às vezes bem definidas, às vezes desconfiguradas na relação tensa com a urbanização.

As cidades estudadas são profundamente marcadas pela incidência e distribuição das estruturas ambientais. As imagens aéreas mostram uma impressionante expressividade de sua inserção nos tecidos urbanos. Entretanto, se na cidade tradicional os espaços livres públicos mostram-se legíveis e passíveis de serem percorridos, no tecido urbano alargado esta relação, na maior parte das vezes, se degrada ou é simplesmente ignorada ou desqualificada. As praias são um exemplo que comporta vários tipos de relação entre cidade e estruturas ambientais. A cidade de Santos tem uma das relações mais generosas e amigáveis com um grande passeio ajardinado entre o edificado e a praia propriamente dita. Esta relação se repete com diferentes graus de generosidade $\mathrm{e}$ publicidade nas diferentes cidades analisadas. A relação entre cidade e estruturas ambientais realmente se degrada nas urbanizações mais recentes, reconhecíveis apenas na escala territorial. Variam de situações onde a legibilidade ocorre apenas como borda de vias expressas, para outras de bordas indefinidas e ocupadas onde a visibilidade fica comprometida, passando por situações onde a relação se dá através de sua negação, de uma separação murada.

Enfim, é possível afirmar ainda que as estruturas ambientais têm $\mathrm{o}$ poder de condicionar a urbanização do território e isso é bastante visível nas cidades analisadas. Além disso, do ponto de vista legal as restrições ambientais se tornaram mandatórias. Portanto, mesmo com dificuldades em diferentes níveis, sua influência sobre a ocupação do território é cada vez mais visível e, como contraponto, ficaram também mais visíveis as situações de tensão e de degradação a que estão submetidas estas estruturas. 


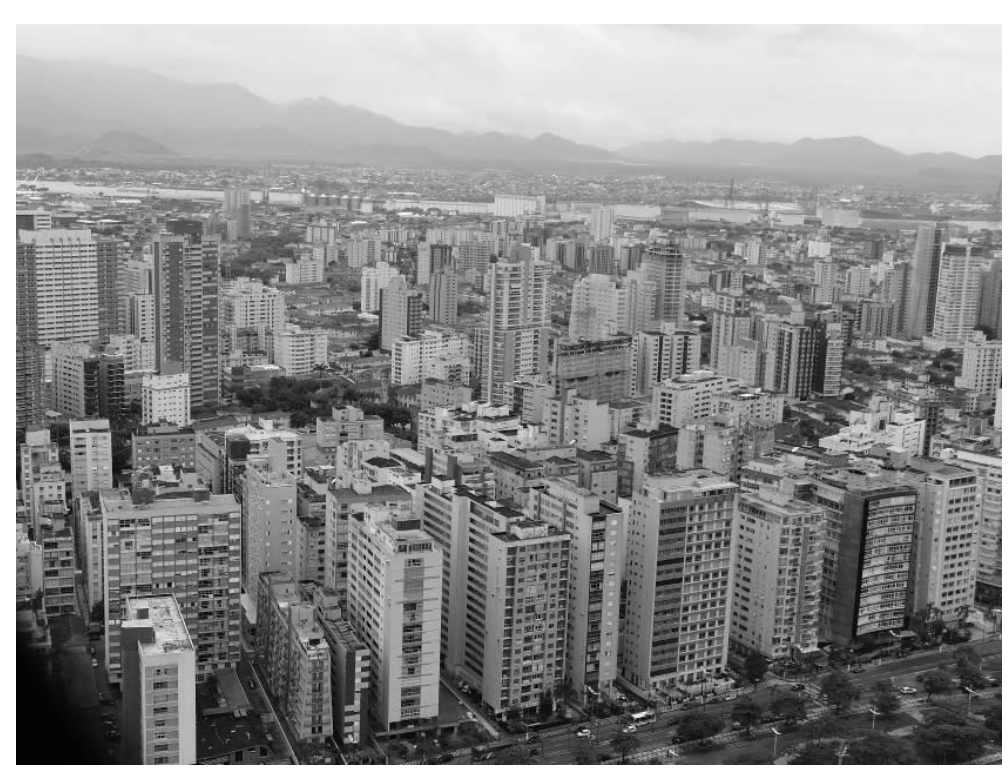

\section{Figura 18. Santos - Tecido compacto predominantemente vertical (fonte: QUAPÁ-SEL, 2014).}

\section{Considerações finais}

Ao debatermos sobre as análises e relatórios, mapas e imagens das cidades estudadas, pudemos tecer algumas considerações que se referem a tendências de ocupação futura, possíveis indicadores de generalização e aspectos singulares que particularizam as cidades.

Em Recife, observam-se vetores potenciais de desenvolvimento e de mudança da forma urbana. Inexiste a predominância de um tipo de processo: são iniciativas neoliberais (privadas e públicas, federais, estaduais e municipais), que congregam verticalização, renovação viária e implantação de parques, com pequenos projetos do programa MCMV.

Em Maceió, consolidam-se as ocupações segundo a ordem de segregação imposta: na planície litorânea central e norte, observa-se a concentração de ocupações por populações de alta renda; na planície lagunar, incidem as ocupações por populações com baixa renda.

Essa segregação é condicionada pelo suporte físico, pois nos tabuleiros de ocupação recente situam-se os conjuntos habitacionais de interesse social, tornando esses espaços mais adensados. O tabuleiro consolidado apresenta ilhas de condomínios de alta renda, e a periferia concentra os condomínios do programa MCMV.
Em Salvador e Vitória, são previstos a diminuição dos espaços livres e os processos intensos de verticalização e adensamento junto às novas vias e corredores de transporte, com aumento da ocupação dos morros, mesclando-se ocupações de populações de alta e baixa renda.

Em Santos, devido ao valor do solo, a área continental é o único setor com áreas disponíveis para os investimentos do mercado, pois concentram terrenos maiores. Ocorre também um processo de (re)ocupação de terrenos que foram objeto da relocação de indústrias ou de equipamentos obsoletos e de expulsão da população de baixa renda para outras cidades da Região Metropolitana da Baixada Santista.

Concluindo nossa análise, podemos ressaltar alguns aspectos que singularizam cada cidade e que apontam contrastes significativos nos aspectos levantados durante as Oficinas.

$\mathrm{O}$ primeiro se refere ao território e à região onde se inserem as cidades, pois é nítida a diferença entre aquelas situadas na região Nordeste e aquelas localizadas no Sudeste. As condições que pautam a economia dessas regiões são elementos que historicamente e culturalmente as diferenciam seja através de índices como Indice de Desenvolvimento Humano e Produto Interno Bruto per capita, seja 

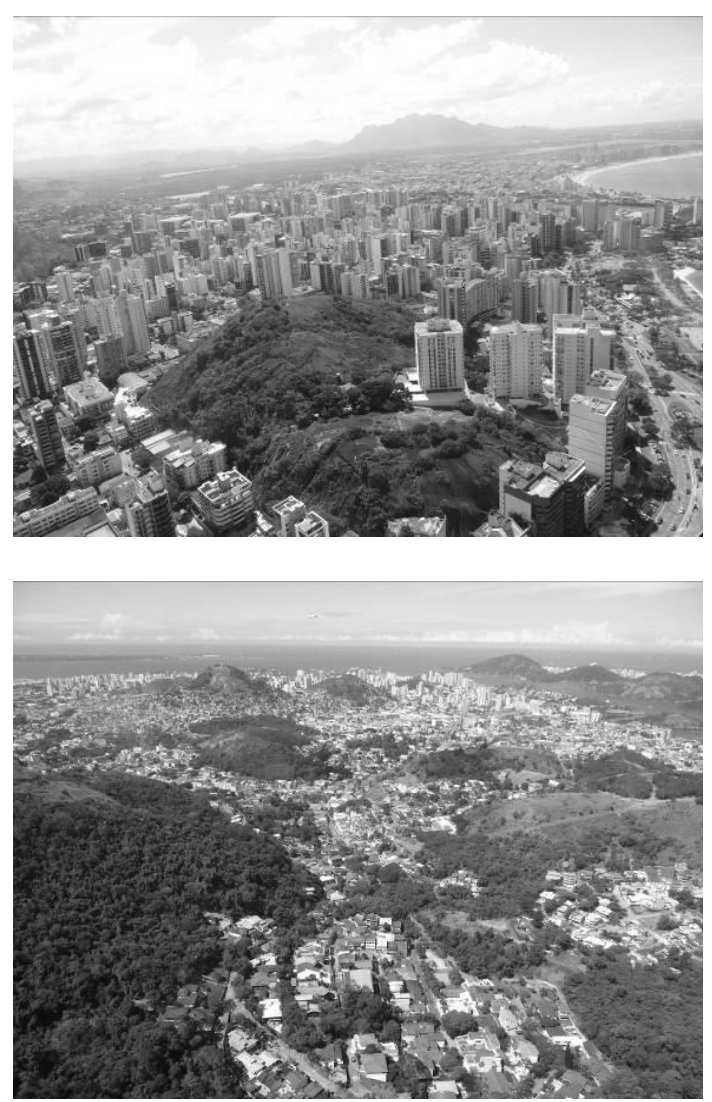

Figura 19. Vitória: (a) ocupação de encostas em padrão de renda alta; (b) pressão sobre as estruturas ambientais

(fonte: QUAPÁ-SEL, 2014).

através das paisagens sociais que nelas se observam (Tângari, 2013b).

$O$ segundo se relaciona ao suporte geobiofísico. Mesmo localizadas em setores onde o bioma original é a Mata Atlântica, as cidades do Nordeste situam-se nas faixas de transição para o bioma de caatinga, onde solo e clima não favoreceram as principais culturas econômicas que impulsionaram a urbanização litorânea no Brasil, como extração de madeira, mineração, cultivos de cana de açúcar e café. As condições geobiofísicas encontradas nas cidades de Sudeste foram definitivas para seu desenvolvimento por possibilitar, em graus distintos, as culturas descritas.

$\mathrm{O}$ terceiro se refere à gênese, à história política e à função administrativa de cada cidade: aquelas que exerceram funções de sedes de governo no período colonial, como Santos, Salvador e Recife; aquelas que permaneceram como capitais de estado, onde disputam ações de governos estaduais e municipais, como Recife, Maceió, Salvador, Vitória; e aquelas que, segundo o Instituto Brasileiro de Geografia e Estatística, exercem maior protagonismo como metrópoles, tais como Salvador e Recife (IBGE, 2007).

O quarto relaciona as condições descritas às funções econômicas exercidas nas cidades e nas suas regiões de influência. Nesse sentido, atuam como diferenciais as instalações portuárias associadas a complexos de atividades extrativistas, com polos petroquímicos ou de mineração. Nesse caso se enquadram as cidades de Salvador e Vitória, e principalmente Santos. Na outra ponta, se inserem as cidades que funcionam como centros mistos de serviços e polos turísticos, como Recife e Maceió.

Acrescentamos que as considerações feitas não esgotam as amplas possiblidades de entendimentos sobre forma urbana e espaços livres expressas pelas paisagens das cidades estudadas e relatadas nos relatórios, cartografias e iconografias produzidos pelo Laboratório QUAPÁ-SEL da Faculdade de Arquitetura e Urbanismo da Universidade de São Paulo. Sinalizam apenas que devemos prosseguir e tentar aprofundar nossos debates, alimentados pelo importante acervo que a rede de pesquisadores tem a seu alcance, e dispostos a enfrentar as novas realidades urbanas das nossas cidades que as informações reunidas e cruzadas a todos descortinam.

\section{Nota}

Esse artigo foi elaborado com base nos relatórios das oficinas QUAPA-SEL realizadas nas cidades de Recife, Maceió, Salvador, Vitória e Santos, com autoria dos pesquisadores e colaboradores das equipes responsáveis por projeto temático a cargo da FAUUSP (coordenação), PUCCampinas e IAU-USP.

\section{Agradecimentos}

Agradecemos aos auxílios concedidos pelo CNPq, FAPERJ, FAPESP, CAPES, UFRJ e PUC-Campinas para o desenvolvimento da pesquisa e elaboração desse artigo. 


\section{Referências}

Ab'Sáber, A. N. (2003) Os domínios de natureza no Brasil: potencialidades paisagísticas (Ateliê Editorial, São Paulo).

Ascher, F. (2010 [2001]) Novos Princípios do urbanismo (Livros Horizonte, Lisboa).

Carvalho, J. (2003) Formas urbanas (Ed. Minerva, Coimbra).

Certeau, M. de (2011[1984]) A invenção do cotidiano (Ed. Vozes, Petrópolis).

Clément, G. (2003) Le Manifeste du TiersPaysage (Editions Sujet / Objet, Paris).

IBGE (2007) Regiões de influência das cidades (Ministério do Planejamento, Orçamento e Gestão, Brasília).

Lamas, J. (1992) Morfologia urbana e desenho da cidade (Fundação Calouste Gulbenkian, Lisboa).

Parahyba, N. (2014) Urbanização contemporânea em Campinas: a dinâmica dos espaços livres, Tese de Mestrado não publicada, PUC-Campinas, Brasil.

Portas, N., Domingues, A. e Cabral, J. (2007) Politicas urbanas: tendências, estratégias $e$ oportunidades (Fundação Calouste Gulbenkian, Lisboa).

Portas, N., Domingues, A. e Cabral, J. (2011) Politicas urbanas II: transformações, regulação e projetos (Fundação Calouste Gulbenkian, Lisboa).

Secchi, B. (2009[2005]) A cidade do século vinte (Ed. Perspectiva, São Paulo).

Silva, J. e Lima, F. (2014) 'Urban form and land value: morphological types and patterns from spatial segregation in Campinas, SP, Brazil', em Oliveira, V., Pinho, P., Mendes, L., Patatas, T. e Monteiro, C. (eds.) Our common future in urban morphology (FEUP, Porto) 1269-80.

Solà-Morales, I. (2002) Territórios (Ed. Gustavo Gilli, Barcelona).

Tângari, V. (1999) Um outro lado do Rio, Tese de Doutoramento não publicada, Universidade de São Paulo, Brasil.

Tângari, V. (2013a) 'A configuração da paisagem urbana no Rio de Janeiro: identificando os tipos morfológicos dos subúrbios ferroviários da zona norte', em Pinto, N. e Almeida, A. (eds.) Annual Conference of Portuguese Network of Urban Morphology (Universidade de Coimbra, Coimbra) 1135-47.

Tângari, V. (2013b) 'A construção social das paisagens no Brasil: um debate conceitual e metodológico', XV ENAMPUR, Recife, 20 a 24 de Maio.

Valor Econômico, 10/02/15, 'Programa Minha Casa, Minha Vida reforça isolamento de mais pobres nas periferias'.

\title{
Tradução do título, resumo e palavras-chave
}

The process of production and transformation of urban form in Brazilian coastal cities

\begin{abstract}
The universe of the national research, sponsored by FAPESP through the thematic project 'Open spaces and urban form' coordinated by QUAPÁ-SEL laboratory, in FAUUSP, encompasses 35 cities, among state capitals and medium-sized cities in Brazil. It is based on procedures that include: individual and group network surveys; workshops held in the cities studied; annual research colloquiums; presentations in national and international scientific events. This paper focuses on five cities located on the coast of Brazil where workshops have already taken place in 2014 and 2015, and have made possible the analysis of some results through comparative approach: Vitória, Salvador, Maceió, Santos and Recife. The text includes reflections and comparisons between cities and concludes by indicating for discussion some criteria of intervention in the studied cities that could generate urban quality, safeguarding the particular socio-environmental situations. In this paper, instead of discussing all the research issues, proposed for the workshops carried out by the QUAPA-SEL network, we have decided to focus only in some of them that have in common the fact they relate to the location along the Brazilian coast. The reflection was based basically on the results of the workshops, which brings to this analysis a simplification and, at the same time, a difficulty. The workshops and their reports are presented in a very heterogeneous and uneven manner. However, the discussions were always based on the same lines of research, ensuring, on the other hand, homogeneity in our approach.
\end{abstract}

Keywords: urban form, open spaces, coastal line, QUAPÁ-SEL, Brazil 